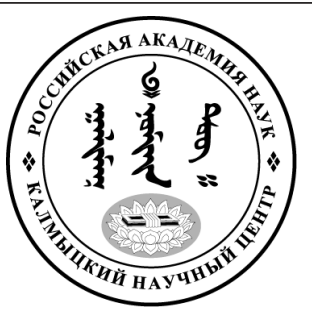

Published in the Russian Federation

Oriental Studies (Previous Name: Bulletin of the Kalmyk Institute

for Humanities of the Russian Academy of Sciences)

Has been issued as a journal since 2008

ISSN: 2619-0990; E-ISSN: 2619-1008

Is. 5 , pp. $812-821,2019$

DOI: $10.22162 / 2619-0990-2019-45-5-812-821$

Journal homepage: https://kigiran.elpub.ru

УДК 903.5+397.4

\title{
Поза всадника по археологическим и этнографическим данным
}

\author{
Мария Александровна Очир-Горяева \\ ${ }^{1}$ Калмыцкий научный центр РАН (д. 8, ул. И. К. Илишкина, 358000 Элиста, Российская Федера- \\ ция) \\ доктор исторических наук, ведущий научный сотрудник \\ ORCID: 0000-0002-0210-7595. E-mail: mariaochir@gmail.com
}

Аннотация. Цель. Статья посвящена анализу и интерпретации двух видов специфической позы погребенных из курганных захоронений скифо-сарматской эпохи степей Евразии. Специфические позы зафиксированы при расположении умерших на спине вытянуто. Особенность этих поз заключается в широко расставленных обеих ногах («танцующая поза»), а также одной отставленной в сторону ноге («атакующая поза»). Материалы. Специфические позы не являются массовым признаком и, по наблюдениям автора статьи, более характерны для погребений кочевой знати. В литературе высказывались различные объяснения для указанных поз погребенных. Автор опирается на высказанное В. О. Обельченко предположение относительно курганов Согда II-I вв. до н. э., что поза с широко раставленными ногами является следствием доставки умершего к могиле верхом на лошади. Для степной зоны Евразии свидетельством существования обряда доставки умерших верхом на лошади служит изображение на золотой обойме из Сибирской коллекции Петра I, где изображены трое умерших, посаженных в седло: один, поддерживаемый в вертикальном положении сидя, и два, уложенных на холку коня. В качестве свидетельства посадки, соответствующей «атакующей позе» погребенных, привлекается изображение на Бахчисарайской стеле II-III вв., относимой к следам сарматского пребывания на Крымском полуострове. Ширина подола юбки Укокской принцессы пазырыкской культуры Горного Алтая служит, по мнению автора, косвенным свидетельством, что Укокская принцесса как знатная особа использовала боковую посадку для ее торжественных выездов, и, скорее всего, таким же образом она была доставлена к могиле. В качестве дополнительного аргумента привлекаются данные по погребальной обрядности тюрко-монгольских народов, в которых имеются прямые и косвенные данные о транспортировке умерших верхом на лошади. Для посадки с обеими ногами на одну сторону привлекаются данные по посадке женщин на ослах до настоящего времени в южных регионах (Узбекистан, Турция), а также картина европейского художника XVII в., на которой изображена крестьянка на осле. Bыводы. Таким образом, установлено, что «танцующая» и «атакующая» позы погребенных связаны с транспортировкой умерших посаженными в седло согласно древнему обычаю евразийских кочевников, сохранившемуся до исторического времени.

Ключевые слова: погребальный обряд, курганы, скифы, сарматы, кочевая элита, Евразия, всадники, посадка в седле, Укок, Бахчисарай, Согд

Благодарности. Исследование выполнено в рамках государственной субсидии - проект «Комплексное исследование процессов общественно-политического и культурного развития народов Юга России» (номер госрегистрации: АААА-А19-119011490038-5). 
Автор выражает благодарность доктору исторических наук А. И. Симоненко, сотруднику Института археологии Национальной Академии наук Украины, взявшему на себя труд критической оценки статьи как специалист по скифо-сарматской эпохе, а также как опытный конник с многолетним стажем.

Для цитирования: Очир-Горяева М. А. Поза всадника по археологическим и этнографическим данным. Oriental Studies. 2019; (5): 812-821. DOI: 10.22162/2619-0990-2019-5-812-821.

UDC $903.5+397.4$

\title{
Body Postures of Buried Horsemen: Archaeological and Ethnographic Evidence
}

\author{
Maria A. Ochir-Goryaeva ${ }^{1}$ \\ ${ }^{1}$ Kalmyk Scientific Center of the RAS (8, Ilishkin St., Elista 358000, Russian Federation) \\ Dr. Sc (History), Leading Research Associate \\ ORCID: 0000-0002-0210-7595. E-mail.mariaochir@gmail.com
}

\begin{abstract}
Goals. The article analyzes and interprets two specific body postures typical for mound Scytho-Sarmatian burials of Eurasian steppes. The postures were traced among ones buried face up in a horizontal position, being distinguished by straddled legs ('dancing pose') or one leg placed aside ('pose of attack'). Materials. The specific postures are not a mass phenomenon, and tend to characterize burials of nomadic nobility. Some earlier works provide different hypotheses interpreting the mentioned fact. The study is based on V. Obelchenko's assumption - regarding $2^{\text {nd }}-1^{\text {st }}$ century BC Sogdian mounds - the straddled legs posture resulted from that dead individuals used to be delivered to their graves mounted on horsebacks. The ritual of delivering the dead mounted on horsebacks in Eurasian steppes is evidenced by a gold plaque from the Siberian Collection of Peter I depicting three corpses mounted onto saddles: one sitting supported up and two others with their heads lying on the horses' shoulders. The 'pose of attack' is evidenced by the $2^{\text {nd }}-3^{\text {rd }}$ century Bakhchysarai Stela believed to be a Sarmatian trace in the Crimean peninsula. The width of the bottom of the Siberian Ice Maiden's skirt might also attest to that as a noble woman she could have mounted sideward on solemn occasions, and is likely to have been delivered to the burial site in a similar position. Additional arguments have been borrowed from funeral rites of the Turko-Mongols directly and indirectly indicating horse mounted transportation of the dead. The one side legs seat is illustrated by present-day women's donkey mounting in southern regions (Uzbekistan, Turkey) and a $17^{\text {th }}$-cenury European artist's canvas depicting a peasant woman on a donkey. Conclusions. So, the paper concludes the 'dancing' and 'attacking' poses of the buried are associated with horse (saddle) mounted transportation of the dead pursuant to the ancient tradition of Eurasian nomads that survived till historical times.
\end{abstract}

Keywords: funeral rites, mounds, Scythians, Sarmatians, nomadic nobility, Eurasia, horsemen, seat, Ukok, Bakhchysarai, Sogdia

Acknowledgements: The reported study was funded by government subsidy — project name 'Socio-Political and Cultural Development of South Russia's Peoples: a Comprehensive Research of Respective Processes' (state reg. no. AAAA-A19-119011490038-5).

The author extends gratitude to Dr. A. Simonenko from the Institute of Archaeology (National Academy of Sciences of Ukraine) who, being an expert in Scytho-Sarmatian era and an experienced horseman, has conducted a critical analysis of the article manuscript.

For citation: Ochir-Goryaeva M. A. Body Postures of Buried Horsemen: Archaeological and Ethnographic Evidence. Oriental Studies. 2019;(5): 812-821 DOI: 10.22162/2619-0990-2019-455-812-821. 


\section{Введение}

В курганных захоронениях скифо-сарматской эпохи степей Евразии встречается два вида специфической позы погребенных, которые зафиксированы при расположении умерших на спине вытянуто. Особенность этих поз заключается: в широко расставленных обеих ногах («танцующая поза»), а также одной отставленной в сторону ноге («атакующая поза»). Специфические позы зафиксированы в основном в погребениях кочевой знати. Приведенные выше определения - «танцующая» и «атакующая» позы - использовались в публикациях 1960-х гг. [Смирнов 1964: 92]. В публикациях последующих лет эти термины перестали использоваться, авторы публикаций обычно пишут, что погребенный был положен на спину «с широко раскинутыми ногами и руками» без всяких дополнительных комментариев. В данной статье предпринимаются анализ и интерпретация указанных двух видов специфической позы погребенных из курганных захоронений скифо-сарматской эпохи степей Евразии.

\section{Основная часть}

Погребения с указанными выше позами не являются массовыми, но встречаются в тех археологических культурах степной зоны Евразии, начиная с эпохи раннего железа до средневековья, в которых погребенные были положены на спину. Исключение составляют такие культуры, как пазырыкская Горного Алтая, алдыбельская и саглынская культуры Саянского нагорья, в которых погребенные были положены на боку скорченно или на боку вытянуто с подогнутыми ногами.

Попыталась объяснить это явление Р. Ролле: она предположила возможность ритуального изнасилования перед смертью или постмортально, но это, по ее же мнению, не обьясняет расположения с широко расставленными ногами мужских скелетов [Berg, Rolle, Seemann 1981: 142-144. Abb. 139-140]. Существует мнение, что ноги первоначально были поставлены на ступни коленями вверх, а в процессе археологизации распались на обе стороны [Скрипкин
1984: 74]. Но в таких случаях ступни находятся близко и параллельно друг другу, как в ямных погребениях бронзового века. В рассматриваемых же погребениях ноги не просто согнуты в коленях, они расставлены, т. е. ступни расположены на расстоянии друг от друга. Позы погребенных с широко расставленными ногами в курганах Согда II-I вв. до н. э. были рассмотрены В. О. Обельченко: он привел аргументацию и высказал мнение, что расставленные ноги погребенных свидетельствуют о доставке трупа к могиле посаженным в седло [Обельченко 1992: 118-120]. Он заметил, что руки погребенных в этих случаях также раскинуты в стороны. Иногда левая рука согнута в локте и отведена в сторону, то есть рука как бы держала повод. Правая же рука или незначительно согнута, или вытянута, как если бы в ней находилась нагайка. Поэтому В. О. Обельченко ввел определение «поза всадника».

А. В. Симоненко высказал сомнение в правильности такой интерпретации позы, когда «руки и ноги слегка согнуты в локтях и коленях, и раскинуты», и обращал внимание на связь этой позы с высоким социальным статусом погребенных. Более того, он высказывал предположение, что сарматские аристократы были выходцами из Средней Азии (долина р. Заравшан), из тех же районов, о которых писал В. О. Обельченко, и поэтому логично предположить, что поза всадника была их этническим признаком, обычаем их предков [Симоненко 2012: 211-212]. Результаты данного небольшого исследования показывают, что археологические и этнографические источники не противоречат связи специфических поз с высоким социальным статусом погребенных, но показывают, что транспортировка умерших к могиле на лошади была основной причиной «танцующей» и «атакующей» поз.

Для изучения были собраны примеры из царских курганов скифов Северного Причерноморья. В боковой гробнице скифского царского кургана Толстая могила все погребенные: двухлетний ребенок, служанка (в ногах), охранник (в головах) и возничий (около колес) - все были расположены с 
широко расставленными ногами. А особа знатного рода, т. е. главная погребенная, в этой гробнице была положена в позе «атакующей» - левая нога выпрямлена, а правая - согнута (рис. 1).

В насыпи 2 скифского кургана Соболева Могила знатный воин был расположен в позе всадника (рис. 2). Пожилая дама - «царица» из Мелитопольского кургана - была также положена в позе всадника. «Установлено, что скелет лежал посередине камеры вытянуто на спине, головой к выходу, на северо-восток, с широко раскинутыми ногами» [Тереножкин, Мозолевский 1988: 31]. В парном погребении кургана 8 Елизаветовского (Пятибратнего) могильника на Нижнем Дону северный скелет, не подвергнутый ритуальному разрушению, был расположен на спине, головой на запад, с широко раскинутыми ногами [Копылов 2004: 34]. В рядовых захоронениях специфические позы более редки [Фиалко 2014: 37, рис. 6, 5].

В более позднюю сарматскую эпоху в целом ряде погребений кочевой знати фиксируется положение погребенных обоих полов с раскинутыми руками и широко и не очень широко расставленными ногами: Пороги (мужчина) [Симоненко, Лобай 1991: 9, рис. 3], Соколова Могила (пожилая женщина) [Ковпаненко 1986: 14, рис. 6], Оланешты, курган 4 (мужчина) [Симоненко 2012: 211], Весняное (мужчина) [Симоненко 2012: 221, рис. 1], Ногайчинский курган (женщина средних лет) [Зайцев, Мордвинцева 2003: 66, рис. 3], Никольский могильник, курган 12 (мужчина) [Засецкая 1979: 98, 101, рис. 12, 3].

В эпоху средневековья погребения с «танцующей» или «атакующей» позами уже не встречаются. Связано это, думается, с распространением мировых религий, которые, как известно, не приветствовали крайние проявления языческих верований. Например, у калмыков обряд сопогребения верхового коня (коней) вместе с хозяином оказался под запретом по политическим мотивам, ввиду сложного политического и военного положения, для сохранения поголовья лошадей. Также известно, что в 1578 г. после встречи Алтан-хана туметского и Далай-ламы был принят закон о десяти добродетелях (буддистского толка) и положение о запрете жертвоприношений лошадьми и верблюдами во время погребения знатных монголов. Предназначенных для погребальной церемонии коней положено было сдавать в буддийский хурул [Бакаева 2010: 270282; История Калмыкии 2009: 244, 302].

Выходит, что языческие обряды были настолько устойчивы, что запретительные меры были приняты не один раз и по разным причинам. Тем не менее, обряд транспортировки на коне и сопогребения его с хозяином продолжал существовать в среде монголоязычных народов до исторических времен. На основе письменных источников XVIII в. установлено, что старого полководца армии хана Галдан Бошокту хоронили по обычаям предков - везли на боевом коне к месту погребения [Ринчен 1972: 121].

Обряд выноса покойника и вывоза его сидящим в седле прослеживается в калмыцком свадебном обряде, когда невесту выносили из юрты родителей, сажали в седло, вдевали ее ноги в стремена, сопровождающий сидел на крупе коня и обязан был поддерживать невесту, которая согласно обряду должна раскачиваться из стороны в сторону. Невеста ритуально умирает для своих родных как незамужняя девушка и «оживает» только в доме жениха, по дороге к которому ей не позволяли ногами касаться земли [Шараева 2008: 91-99; Очир-Горяева 2014: 28-32].

Отголоском древнего обычая сопровождения умершего конем можно считать сохранившийся до второй половины XIX в. в среде калмыков вынос сбруи коня следом за покойным хозяином через разобранную часть решетки юрты ${ }^{1}$ [Бакаева 2010: 271].

Обряд доставки умершего верхом на коне широко практиковался у других тюрко-монгольских народов, в большей степени, чем калмыки, сохранивших языческие обряды: бурят, алтайцев, тувинцев. По сведениям этнографов, буряты везли покойника к месту захоронения на его лучшем коне, оседланном и в лучшей сбруе. Покойного сажали верхом, поддерживали с двух сторон; коня вел на поводу один из участников похорон. На покойника надевали его полное вооружение. По пути одной из его стрел выстреливали в сторону дома, возвращаясь с похорон, ее подбирали и брали с собой в дом. Алтайцы, по сообщениям информато-

1 По калмыцким обычаям дверь юрты использовалась только живыми, для выноса покойника разбирали стену юрты с восточной стороны. 
ров, покойника везли на место захоронения верхом, посадив его впереди себя в седло. Тувинцы после выноса умершего из юрты везли к месту погребения на лошади. Покойника везли на верховой лошади перекинутым через седло. Позади седла сидел сопровождающий тело. В некоторых случаях помещали умершего на седло верховой лошади и везли его в сидячем положении. Позади сидел сопровождающий и поддерживал труп. Мужчину всегда везли на верховой лошади, заседланной его личным седлом. Женщину-покойницу везли на лошади только в том случае, если у нее была личная лошадь и седло, в остальных случаях везли на сарлыках (яках) [Семейная обрядность... 1980: 93; Дьяконова 1975: 44].

Ярким доказательством обряда транспортировки умерших на коне верхом в скифо-сарматскую эпоху свидетельствует изображение группы всадников на развертке золотого цилиндрического футляра из Сибирской коллекции Петра 1 , датирующейся классическим скифским временем в рамках V-III вв. до н. э. В центре композиции показан посаженный в седло мертвый человек с опущенной на древко копья головой и согнутой безвольно спиной. Его придерживает с помощью палки едущий рядом всадник. Два других трупа посажены в седло и уложены на холку коня [Очир-Горяева 2012: форзац; Очир-Горяева 2018: 67-73].

Второй вид специфической позы погребенных («атакующая» поза), когда одна нога располагается прямо, а другая слегка согнута в колене и ступней направлена в сторону, также находит подтверждение в археологических и исторических источниках. Судя по рельефному изображению двух всадников на Бахчирсарайской стеле сарматского круга из Крыма, в эпоху ранних кочевников была известна посадка на коне с ногами по одну сторону лошади [Чореф, Шульц 1972: 135-145]. Стела датируется II-III вв. по иконографическим особенностям и по тамгам, нанесенным на ней, и отнесена авторами публикации к древностям позднесарматского времени. Стела была обнаружена случайно во время плантажной вспашки в 1969 г. в урочище Рамазан-сала под Бахчисараем (рис. 4). На стеле в рельефе нанесено изображение двух всадников (всадниц) в необычной посадке, «по-женски», как отметили авторы публикации, т. е. с ногами по одну сторону лошади. У обоих всадников правая ступня направлена носком по ходу движения лошади, а левая нога свисает свободно вниз. Корпус всадников изображен во фронтальной проекции. Авторы публикации полагали, что лошади резко остановились, как бы «осажены», поэтому их прямо вытянутые ноги расположены под углом, соответственно корпус обоих всадников тоже несколько наклонен по ходу движения. Авторами публикации было также замечено, что передние ноги лошадей расположены несколько выше задних, так же как и на других рельефах сарматского круга с изображением всадников. Как отмечали авторы, наклонное положение лошадей и всадников делает непонятным, застыли они или находятся в движении. На мой взгляд, все объясняется просто, всадники на своих лошадях движутся по склону наверх, как бы в гору, отсюда разница в расположении передних и задних ног лошадей и наклонное положение всадников. Движением в гору обьясняется и расположение правой ступни всадников носком вперед. Фигуры всадников изображены фронтально, и только ступня правой ноги повернута носком по ходу движения. На лошадях показаны только повод и узда, седельные ремни не показаны. Получается, всадники сидят на лошади без сбруи и седла. В таком случае с помощью правой ноги, прижатой к корпусу лошади, возможно, тормозилось скольжение всадников вниз по спине лошади ${ }^{2}$.

В любом случае изображение на Бахчисарайском рельефе фиксирует древний существовавший и в Европе до XIV в. способ, когда знатные всадницы сидели на коне, как на скамье. Потребность в боковой посадке привела позднее к изобретению верхней двойной луки для женского

2 Авторами публикации Бахчисарайского рельефа замечена интересная деталь, что все всадники на изображениях сарматского круга скачут наверх, в гору. Полагаю, это связано с представлениями о хорошем значении, когда всадники направлены всегда слева направо, т. е.по ходу солнца, и всегда наверх, к небесам. Сужу по реакции старшего поколения калмыков, не понимавших, почему бывший глава Калмыкии установил при въезде в Элисту золоченую статую всадника, который скачет в сторону захода солнца, на запад. «Му йор» - говорили они, т.е. нехорошее значение, смысл. 
седла, что позволило развернуть корпус всадницы паралелльно плечам лошади и обеспечило большую безопасность и контроль над лошадью. Простолюдинки в южных регионах использовали боковую посадку при езде на осликах. Об этом свидетельствует картина нидерландского художника Николаса Берхема «Итальянский ландшафт с упорным ослом», написанная им в 1655 г. (рис. 5). В Узбекистане, Турции до недавнего времени в деревнях можно было увидеть женщин, использующих такую посадку на ослах ${ }^{3}$.

Надо полагать, что и с мягким седлом, использовавшимся кочевниками раннего железного века Евразии, и вовсе без седла, боковая посадка имела серьезные ограничения и могла использоваться только в специальных случаях: церемониях, официальном выезде для неспешного движения, не требующего особого управления лошадью. Неслучайно повод у обоих всадников на Бахчисарайском рельефе не натянут, а свободно провисает.

Авторы публикации Бахчисарайского рельефа считали, что оба всадника были представителями мужского пола. Однако предпринятый обзор показывает, что боковая посадка на лошади использовалась только женщинами, и то не всеми, а только знатными, и не всегда, а только во время торжественных выездов. Поэтому будет логичнее интепретировать рельеф на стеле из Бахчисарая как изображение знатных наездниц во время торжественного выезда.

В «атакующей» позе с одной согнутой ногой была положена молодая супруга скифского царя из Толстой могилы (рис. 1). О том, что дамы знатного происхождения, в отличие от простолюдинок, не садились в седло по-мужски, свидетельствует, на мой взгляд, и ширина юбки Укокской принцессы - 0,90-112,5 см, с учетом предположения автора раскопок, что «мешковидный фасон юбки позволял носить ее, меняя верх и низ» [Полосьмак 2001: 114]. Для свободного закидывания ноги через седло и, самое главное, для сидения в седле с ногами, опущенными с обоих боков лошади, необходима ширина юбки, по крайней мере, 1,5 м в шаге. Получается, юбка Укокской принцессы не позволяла ей сидеть в седле по-муж-

${ }^{3}$ Устная информация местных жителей 1959 и 1964 гг. рождения. ски, как показано на реконструции [Полосьмак 2001: 278, рис. 165]. Таким образом, имеются твердые основания полагать, что «танцующая» и «атакующая» позы погребенных связаны с транспортировкой умерших посаженными в седло согласно древнему обычаю евразийских кочевников, сохранившемуся до исторического времени.

Интересен вопрос, почему специфические позы более характерны для погребений знати. Этнографические данные показывают, что к могиле в седле возили всех, у кого была собственная лошадь [Очир-Горяева 2012: 442-445]. Но специфические позы зафиксированы больше в могилах знати. Полагаю, что это связано со временем между наступлением смерти и захоронением. По сведениям Геродота, умершего скифского царя после бальзамирования возили в течение сорока дней по его владениям [Геродот 1972, IV: 71-72]. Закономерно, что похоронные церемонии знатных представителей были в любом случае более длительные, чем простолюдинов, поэтому вполне возможно, что труп успевал затвердеть, и поэтому не всегда удавалось изменить позу умершего при внесении его в могилу.

\section{Заключение}

В данной работе проведен анализ специфических поз погребенных из курганных захоронений степной зоны Евразии от Черного моря до Горного Алтая, охватывающей хронологический период от середины I тысячелетия до н. э. до первых веков нашей эры. Собраны и рассмотрены археологические погребальные памятники указанного периода, образцы изобразительного искусства скифо-сарматского времени, такие как изображение процессии всадников на золотом футляре из Сибирской коллекции Петра I и каменная стела из Крыма с рельефом в виде двух всадников, датируемая позднесарматским временем, а также данные по погребальной обрядности тюрко-монгольских народов. Предложенная О. В. Обельченко интерпретация специфической позы погребенных как следствие транспортировки умерших верхом на лошади подтверждается всем комплексом источников по кочевникам скифо-сарматской эпохи степной зоны. 


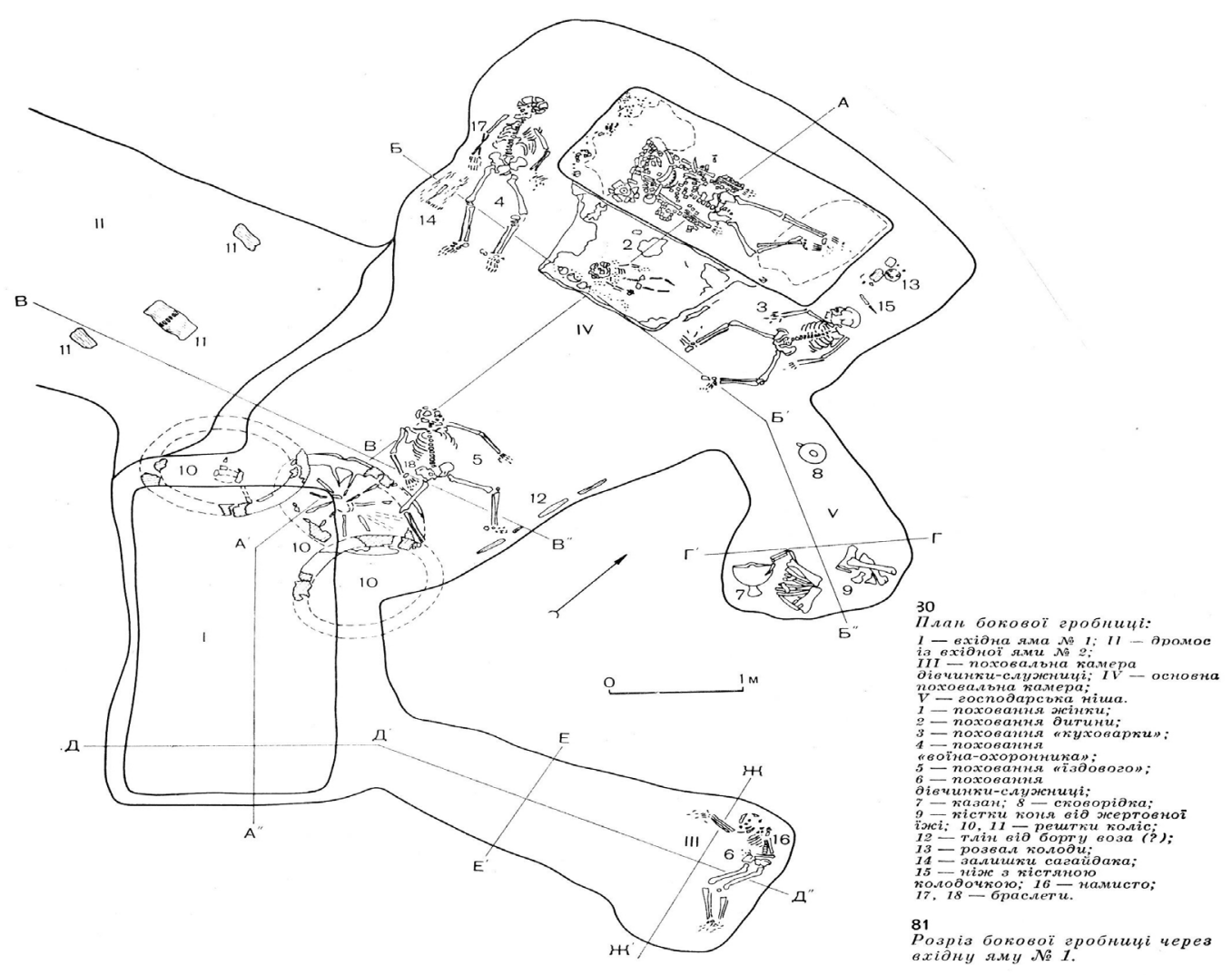

Рuc. 1. Толстая Могила. План боковой гробницы [Мозолевский 1979: рис. 30]

I - входная яма 1, II - дромос из входной ямы 2, III - погребальная камера девочки-служанки, IV - камера основного погребения, V - хозяйственная ниша. 1 - погребение царицы, 2 - погребение ребенка, 3 - погребение «кухарки», 4 - погребение воина-«стражника», 5 - погребение «колесничего», 6 - погребение девочки-«служанки»

[Fig. 1. Tolstaya Mogila. Scheme of the side tomb [Mozolevski 1979: fig. 30]

I - entrance pit 1, II — dromos of entrance pit 2, III — burial chamber of a servant girl, IV — main burial chamber, V - household niche. 1 - burial of a queen, 2 - burial of a child, 3 - burial of a kitchen maid, 4 - burial of a guard, 5 - burial of a charioteer, 6 - burial of a servant girl.]

Рис. 2. Соболева Могила. Погребение 2. План погребальной камеры

[Мозолевский, Полин 2005: 161, рис. 91]

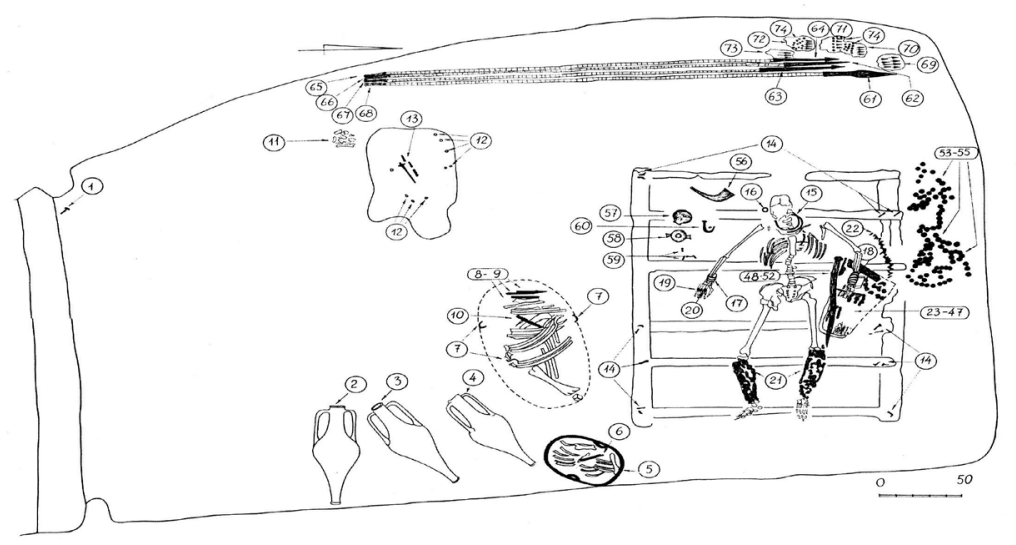

1 - железные скобы деревянного заслона входа в камеру; 2-4 - амфоры; 5 - бронзовый котел; 6 - кости овцы и нож; 7 — железные скобы; 8-10 — ножи; 11 - кучка нарубленных костей; 12 серебряные бусы; 13 костяное веретено; 14-60 - железные скобы и гвозди настила; 15 - золотая гривна; 16 - золотая серьга; 17-18 - золотые браслеты; 19-20 - золотые перстни; 21 - брон- 
зовые поножи; 22 - золотая обмотка нагайки; 23-47 - золотое покрытие горита; 48-52 - железный меч с золотой обкладкой рукояти, фрагменты деревянных ножен, золотая муфта ножен, серебряный коробчатый наконечник ножен, золотая ворворка крепления меча; 53-55 - золотые нашивные бляшки трех типов; 56 - серебряный ритон; 57 - серебряный кубок; 59 - золотые обкладки деревянной чаши; 61-62 - наконечники копий; 63-64 - наконечники дротиков; 65-68 - втоки древок копий и дротиков; 69-73 - колчаны № 1-5; 74 - серебряные бусы.

[Fig. 2. Soboleva Mogila. Burial 2. Scheme of the burial chamber [Mozolevski, Polin 2005: 161, fig. 91] 1 - iron clinches of the entrance wood cover; 2-4 - amphorae; 5 - bronze caldron; 6 - sheep bones and a knife; 7 - iron clinches; 8-10 - knives; 11 - a pile of chopped bones; 12 - silver beads; 13 bone spindle; $14-60$ — iron clinches and nails of the flooring; 15 - gold torque; 16 - gold earring; 17-18 - gold bracelets; 19-20 - gold rings; 21 - bronze greaves; 22 - gold braids of a nagaika; 23-47 — gold covering of a gorytos; 48-52 — iron sword with gold coating, fragments of a wood scabbard, gold barrel hand of the scabbard, square silver top case of the scabbard, gold sword vorvorka (suspender); 53-55 - gold sewn-on plaques of three types; 56 - silver rhyton; 57 - silver cup; 59 gold casing of a wood bowl; 61-62 — spearheads; 63-64 - javelin heads; 65-68 - counter-weights; 69-73 - quivers № 1-5; 74 — silver beads.]

Puc. 3. Пороги. Курган 2, погребение 1. План погребения [Симоненко, Лобай 1991: 9, рис. 3]

1 - меч; 2 - кинжал; 3 - лук; 4 - колчан; 5 - наконечник дротика; 6 - пластина-гастагна; поясные бляхи; 8 - поясные пластины; 9 - портупейная бляха; $10-$ бляшки в виде лотоса; 11 - наконечники свисающих ремней; 12 - наконечники портупейных ремней; 13 портупейные пряжки; 14 - фибулы; 15-16 - обувные пряжки; 17 - гривна; 18 - браслет; 19 - кубок; 20 золотые пронизки.

[Fig. 3. Porogi. Mound 2, burial 1. Scheme of the burial [Simonenko, Lobay 1991: 9, fig. 3]

1 - sword; 2 - dagger; 3 - bow; 4 - quiver; 5 - javelin head; 6 - gastagna; belt plaques; 8 - belt plates; 9 sword-belt plaque; 10 - lotus-shaped plaques; 11 - heads of hanging belts; 12 - heads of sword-belts; 13 - swordbelt plaques; 14 - fibulae; 15-16 - shoe buckles; 17 torque; 18 - bracelet; $19-$ cup; 20 - gold threadings.]

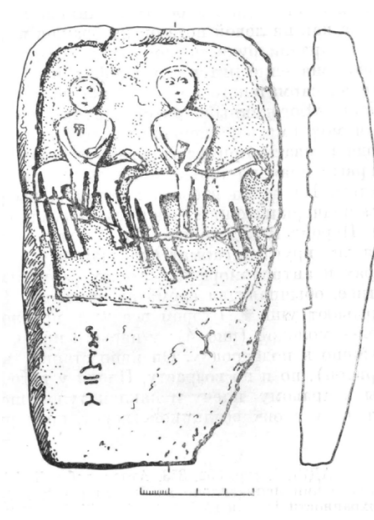

Рис. 4. Рельеф с изображениями двух всадников. Бахчисарайский музей

[Чореф, Шульц 1972: рис. 3].

[Fig. 4. A relief depicting two horsemen. Bakhchysarai Museum [Choref, Schulz 1972: fig. 3]

\section{Puc. 5. Nicolaes Berchem}

(Haarlem 1621/22-1683.

Amsterdam). Italienische

Landschaft mit dem störrischen

Esel. Leinwand. 1655 (= Николас

Берхем

(Хаарлем 1621/22-1683. Амстердам.). Итальянский ландшафт с упорным ослом. Масло. 1655 г.).

[Fig. 5. Nicolaes Berchem (1621/22-1683). Italian Landscape with Stubborn Donkey. 1655]
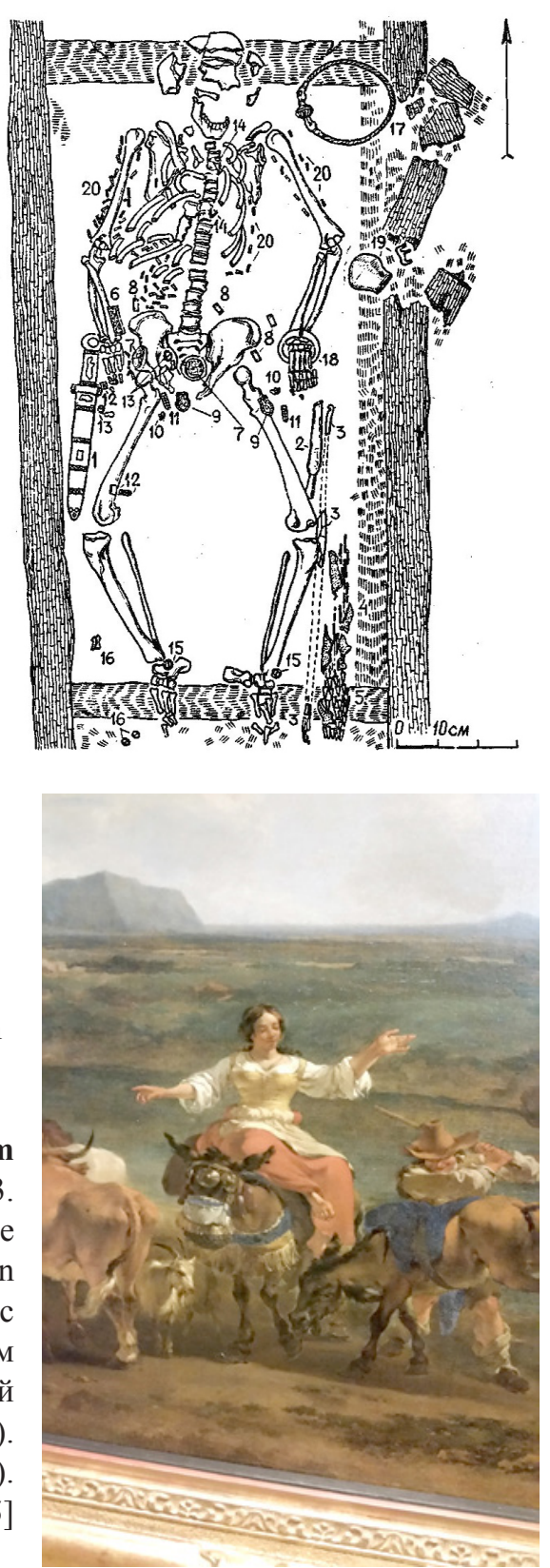


\section{Литература}

Бакаева 2010 - Бакаева Э. П. Похоронно-погребальная обрядность // Калмыки. Серия «Народы и культуры» / отв. ред.: Э. П. Бакаева, Н. Л. Жуковская. М.: Наука, 2010. 586 с.

Геродот 1972 - Геродот. История (в девяти книгах). Перевод и комментарии Стратановского. Л.: Наука, 1972. 600 с.

Дьяконова 1975 - Дьяконова В. П. Погребальный обряд тувинцев как историко-этнографический источник. Л.: Наука, 1975. 164 с.

Зайцев, Мордвинцева 2003 - Зайцев Ю. П., Мордвинцева В. И. «Ногайчинский» курган в степном Крыму // Вестник древней истории. 2003. № 3. С. 66-99.

Засецкая 1979 - Засецкая И. П. Савроматские и сарматские погребения Никольского могильника // Труды ГЭ. Т. ХХ. М.: Искусство, 1979. С. 87-113.

История Калмыкии 2009 - История Калмыкии с древнейших времен. Т. І. Элиста: Герел, 2009. 845 c.

Ковпаненко 1986 - Ковпаненко Г. Т. Сарматское погребение I в. н. э. на Южном Буге. Киев: Наукова думка, 1986. 150 с.

Копылов 2004 - Копьлов В. П. Скифский царский курган Елизаветовского могильника // Сокровища донских степей из собрания Ростовского областного музея краеведения. Ростов н/Д, 2004. С. 41-54.

Мозолевський 1979 - Мозолевський Б. М. Товста Могила. Киев: Наукова Думка, 1979. 213 с.

Мозолевский, Полин 2005 - Мозолевский Б. Н., Полин С. В. Курганы скифского Герроса IV века до н. э. (Бабина, Водяна и Соболева могилы). Киев: Стилос, 2005. 599 с.

Обельченко 1992 - Обельченко О. В. Культура античного Согда. М.: Наука, 1992. 256 с.

Очир-Горяева 2012 - Очир-Горяева М. А. Древние всадники степей Евразии. М.: Таус, 2012. 486 c.

Очир-Горяева 2014 - Очир-Горяева М. А. К вопросу о роли коня в погребальном обряде калмыков // Вестник Калмыцкого института гуманитарных исследований РАН. 2014. № 1. С. 28-32.

Очир-Горяева 2018 - Очир-Горяева М. А. Изображение процессии всадников на золотой обойме из Сибирской коллекции Петра I // Археология, этнография и антропология Евразии. Новосибирск. 2018. Вып. 4 (46). С. $67-$ 73. DOI: $10.17746 / 1563-0102.2018 .46 .4 .067-$ 073.
Полосьмак 2001 - Полосьмак Н. В. Всадники Укока. Новосибирск: ИНФОЛИО-пресс, $2001.335 \mathrm{c}$.

Ринчен 1972 - Ринчен Б. Принцесса. И другие новеллы. М.: Худ. лит., 1972. 184 с.

Семейная обрядность 1980 - Семейная обрядность народов Сибири (опыт сравнительного изучения) / под. ред. И. С. Гурвич. М.: Наука, 1980. 278 с.

Симоненко, Лобай 1991 - Симоненко А. В., Лобай Б. И. Сарматы Северо-Западного Причерноморья в I в. н. э. (погребения знати у с. Пороги). Киев: Наукова думка, 1991. $110 \mathrm{c}$.

Симоненко 2012 - Симоненко А. В. Золото, конь и человек. Сб. ст. к 60-летию А. В. Симоненко. Киев: КНТ, 2012. 464 с.

Скрипкин 1984 - Скрипкин А. С. Нижнее Поволжье в первые века нашей эры. Саратов: Изд-во Саратовского ун-та, 1984. 149 с.

Смирнов 1964 - Смирнов К. Ф. Савроматы. Ранняя история и культура сарматов. М.: Наука, 1964. 377 с.

Тереножкин, Мозолевский 1988 - Тереножкин А. И., Мозолевский Б. Н. Мелитопольский курган. Киев: Наукова думка, 1988. 264 c.

Шараева 2008 - Шараева T. И. Ритуальная «смерть» и «возрождение» невесты в свадебном обряде у калмыков // Ойраты и калмыки в истории Россиии, Монголии и Китая: мат-лы междунар. науч. конф. (г. Элиста, 9-14 мая 2007 г.). Ч. 3. Элиста: 2008. C. 91-99.

Фиалко 2014 - Фиалко Е. Е. Могилы вооруженных женщин Рогачикского курганного поля // Археологія і давня істория Украіны. Вып. 1 (1). Киів, 2014. С. 25-39.

Чореф, Шульц 1972 - Чореф М. Я, Шульи П. Н. Новый рельеф сарматского круга // Советская археология. 1972. № 1 С. 135-145.

Berg, Rolle, Seemann 1981 - Berg S., Rolle R., Seemann H. Der Archäologie und der Tod Archäologie und Gerichtsmedizin. München, Luzern: C. J. Bucher, 1981. 168 S.

\section{References}

[Family Rites of Siberian Peoples: a Comparative Study]. I. S. Gurvich (ed.). Moscow: Nauka, 1980. 278 p. (In Russ.)

[History of Kalmykia: from the Earliest Times to the Present Days]. Elista: Gerel, 2009. Vol. I. 845 p. (In Russ.) 
Bakaeva E. P. Funeral rites. In: [The Kalmyks]. E. P. Bakaeva, N. L. Zhukovskaya (eds.). Moscow: Nauka, 2010. 586 p. (In Russ.)

Berg S., Rolle R., Seemann H. [Archaeology, Archaeology of Death, and Forensic Medicine] München, Luzern: C. J. Bucher, 1981. 168 p. (In Germ.)

Choref M. Ya, Schulz P. N. A new configuration of the Sarmatian circle. Sovetskaya arkheologiya. 1972. No. 1. Pp. 135-145. (In Russ.)

Dyakonova V.P. [Tuvan Funeral Rites as a Historical and Ethnographic Source]. Leningrad: Nauka, 1975. 164 p. (In Russ.)

Fialko E. E. Tombs of armed women from Rogachyk kurgan area. In: [Archaeology and Ancient History of Ukraine]. Vol. 1 (1). Kiev, 2014. Pp. 25-39. (In Russ.)

Herodotus. The Histories. G. A. Stratanovsky (transl. and comment.). Leningrad: Nauka. 1972. 600 p. (In Russ.)

Kopylov V. P. Elizavetovsky burial site: a Scythian king's mound. In: [Rostov Oblast Museum of Local History and Lore: Treasures of the Don Steppes]. Rostov-on-Don, 2004. Pp. 41-54. (In Russ.)

Kovpanenko G. T. [A $1^{\text {st }}$-century AD Sarmatian burial from the Southern Bug Valley]. Kiev: Naukova Dumka, 1986. 150 p. (In Rus.)

Mozolevski B. M. [Tovsta Mohyla (Tolstaya Mogila)]. Kiev: Naukova Dumka, 1979. 213 p. (In Ukr.)

Mozolevski B. N., Polin S. V. [4 $4^{\text {th }}-$ Century BC Mounds of the Scythian Gerros (Babina, Vodyana and Soboleva Mohylas)]. Kiev: Stilos, 2005. 599 p. (In Russ.)

Obelchenko O. V. [Culture of Ancient Sogdia]. Moscow: Nauka, 1992. 256 p. (In Russ.)

Ochir-Goryaeva M. A. [Ancient Horsemen of Eurasian Steppes]. Moscow: Taus, 2012. 486 p. (In Russ.)

Ochir-Goryaeva M. A. Kalmyk funeral rites: role of the horse revisited. Bulletin of the Kalmyk
Institute for Humanities of the RAS. 2014. No. 1. Pp. 28-32. (In Russ.)

Ochir-Goryaeva M. A. Procession of horsemen on a gold plaque from the Siberian Collection of Peter I. Archaeology, Ethnology \& Anthropology of Eurasia. 2018. No. 4 (46). Pp. 67-73. (In Russ.) https://doi.org/10.17746/15630102.2018.46.4.067-073.

Polosmak N. V. [Horsemen of Ukok]. Novsibirsk: INFOLIO-press, 2001. 335 p. (In Russ.)

Rinchen B. [The Princess. And Other Novels]. Moscow: Khud. Lit., 1972. 184 p. (In Russ.)

Sharaeva T. I. Wedding rites of the Kalmyks: ceremonial death and resurrection of the bride. In: [Oirats and Kalmyks in the History of Russia, Mongolia and China]. Conf. proc. (Elista; May 9-14, 2007). Elista, 2008. Part 3. Pp. 91-99. (In Russ.)

Simonenko A. V. [Gold, Horse and Man]. Coll. articles. Kiev: KNT, 2012. 464 p. (In Russ.)

Simonenko A. V., Lobay B. I. [Sarmatians in the Northwestern Black Sea Region: Burials of Nobility near Porogi, $1^{\text {st }}$ Century AD]. Kiev: Naukova Dumka, 1991. 110 p. (In Russ.)

Skripkin A. S. [The Lower Volga in the Early Centuries AD]. Saratov: Saratov State University, 1984. 149 p. (In Russ.)

Smirnov K. F. [The Savromats: Early History and Culture]. Moscow: Nauka, 1964. 377 p. (In Russ.)

Terenozhkin A. I., Mozolevski B. N. [Melitipol Mound]. Kiev: Naukova Dumka, 1988. 264 p. (In Russ.)

Zasetskaya I. P. Nikolsky burial site: Savromatian and Sarmatian burials. In: [Transactions of the State Hermitage Museum]. Vol. XX. Moscow: Iskusstvo, 1979. Pp. 87-113. (In Russ.)

Zaytsev Yu. P., Mordvintseva V. I. The Nogaichinsky mound in steppes of the Crimea. Vestnik Drevnei Istorii. 2003. No. 3. Pp. 66-99. (In Russ.) 